\title{
EngagedScholarship@CSU
}

2015

\section{Slipping from Secret History to Novel}

Rachel K. Carnell

Cleveland State University, r.carnell@csuohio.edu

Follow this and additional works at: https://engagedscholarship.csuohio.edu/cleng_facpub

Part of the Literature in English, British Isles Commons

How does access to this work benefit you? Let us know!

Publisher's Statement

This work remains under copyright (c) 2014 Eighteenth-Century Fiction, McMaster University, doi: 10.3138/ecf.28.1.1, http://www.utpjournals.press/doi/abs/10.3138/ecf.28.1.1

\section{Recommended Citation}

Carnell, Rachel K., "Slipping from Secret History to Novel" (2015). English Faculty Publications. 78.

https://engagedscholarship.csuohio.edu/cleng_facpub/78

This Article is brought to you for free and open access by the English Department at EngagedScholarship@CSU. It has been accepted for inclusion in English Faculty Publications by an authorized administrator of EngagedScholarship@CSU. For more information, please contact library.es@csuohio.edu. 


\title{
Slipping from Secret History to Novel
}

\author{
Rachel Carnell
}

\section{ABSTRACT}

The secret history, a genre of writing made popular as opposition political propaganda during the reign of Charles II, has been the subject of renewed critical interest in recent years. By the mid1740 s, novelists were using markers of secret histories on the title pages of their works, thus blurring the genres. This forgotten history of the secret history can help us understand why Ian Watt and other twentieth-century critics tended to end their narratives of the rise of the "realist" Whig novel with the works of the Tory novelist Jane Austen. In particular, the blended narrative perspective that Watt praises in Austen's novels-in which the author balances a realism of presentation with a realism of assessment-may stem in part from the layers of narrative framing deployed in secret histories to shield the author from prosecution for libel. The opposition and Tory secret historians that Watt excludes from his Whiggish triple-rise theory may have contributed to the complex narratological perspective that he identifies as the culmination of the novel's formal emergence.

\section{AUTHOR}

Rachel Carnell, professor of English at Cleveland State University, is the author of A Political Biography of Delariver Manley (2008) and Partisan Politics, Narrative Realism, and the Rise of the British Novel (2006); she co-edited, with Ruth Herman, the five-volume Selected Works of Delarivier Manley (2005). 
Sébastien Brémond's Hattigé, ou les amours du Roy Tamaran, nouvelle (1676) relates gossip about Charles II and the Duchess of Cleveland, emphasizing the sway she had over him while she was his maîtresse en titre. ${ }^{1}$ Although lacking the word "secret history" in the title, this work follows the model made popular by seventeenth-century translations of Procopius's Anekdota, a salacious and initially unpublished collection of anecdotes about Emperor Justinian and his wife, which was first published in a Latin translation in 1623 as Historia arcana (Secret History), then translated into French in 1669 as Histoire Secrète and into English in 1674 as The Secret History of the Court of the Emperor Justinian. As Annabel Patterson and Rebecca Bullard have pointed out, these translations of Procopius's subversive counter-history of the very reign for which he also wrote hagiographic official histories caught the interest of seventeenth-century European readers who were concerned about abuses of power at the courts of Louis XIV and Charles II. ${ }^{2}$

Brémond's work, clearly in the genre of the court secret history, used the term nouvelle-meaning a piece of news or gossiprather than the tag histoire secrète on its title page. On the title page of the English translation nouvelle became A Novel. Other Exclusionist secret histories originally written in English, such as The Perplex'd Prince (1683), also used romantic pseudonyms for Charles II and his mistresses, but did not necessarily use the tag "novel" or "secret history." Plenty of publications did use the term "secret history," for example The Secret History of White-hall (1697) and The Secret History of Europe (1712-14). This fluidity of terminology in the late seventeenth century is not surprising given the ways in which readers read at the time. As Lennard Davis observed several decades ago, early modern readers did not make the same distinctions that most twenty-first century readers do between "fact" and "fiction," or between what was "news" about real persons and what was "novel" or "new." 3 More

1 E.P. Grobe establishes that Sébastien, not Gabriel, Brémond wrote Hattigé, in "Gabriel and Sébastien Brémond," Romance Notes 4, no. 2 (1963): 132-35.

2 Annabel Patterson, Early Modern Liberalism (Cambridge: Cambridge University Press, 1997), 183-98; and Rebecca Bullard, The Politics of Disclosure 1674-1725: Secret History Narratives (London: Pickering \& Chatto, 2009), 29-43.

3 Lennard Davis, Factual Fictions: The Origins of the English Novel (New York: Columbia University Press, 1983), 51. 
recently, Kate Loveman has discovered that during this era readers read sceptically, looking for real persons and events; ${ }^{4}$ presumably they did so regardless of whether or not the word "secret" or "history" appeared in the title. As the eighteenth century progressed, and as "the novel" evolved into a form understood as a work of "invention" despite its frequent claims to truth, writers demonstrated increasing awareness of the difference between secret histories, based on real events and persons, and novels as works of fiction, even as they also clearly saw an advantage to marketing the works as "true" or "secret" histories.

In the preface to The Fair Hebrew; Or, A True, But Secret History of Two Jewish Ladies, Who Lately Resided in London (1729), Eliza Haywood plays with the marketing tags of "secret history" and "novel," reflecting on the difference between publications about real events and "so many Things, merely the Effect of Invention, which have been published, of late, as SECRET HISTORIEs." Claiming that she includes no incident that was not told to her by a "Person nearly concerned in the Family" (sig. A1r), she is clearly taking advantage of the appeal of the "secret history" in order to promote her probably fictional work, following the same business model that prompted her to reissue The Works of Mrs. Eliza Haywood; Consisting of Novels, Letters, Poems, and Plays (1725) with the new, less-classical title Secret Histories, Novels and Poems ... by Mrs. Eliza Haywood (1726). ${ }^{6}$ Moving in the opposite direction, Delarivier Manley's best-selling political secret history Secret Memoirs and Manners ... From ... the New Atalantis (1709) was posthumously reissued in 1735 in the Weekly Novellist, a publication described as "Containing a select Collection of the best Novels, Moral, and Political, \&c. with other Pieces of Love and Gallantry."7 By 1785, Clara Reeve would not refer to the term

4 Kate Loveman, Reading Fictions, 1660-1740: Deception in English Literary and Political Culture (Burlington: Ashgate Publishing, 2008), 3-8.

5 [Eliza Haywood], The Fair Hebrew; Or, a True, But Secret History of Two Jewish Ladies, Who Lately Resided in London (London: J. Brindley, 1729), sig. A1r. References are to this edition.

6 On Haywood's decision to reissue her Works, see Bullard, 165. For a more developed discussion of Haywood's use of the tropes of secret history in this and in a range of works across her career, see Rachel Carnell, "Eliza Haywood and the Narratological Tropes of Secret History," Journal of Early Modern Cultural Studies 14, no. 4 (2014): 101-21, doi: http://dx.doi.org/10.1353/jem.2014.0043.

7 London Evening Post (26-28 August 1735), 5. 17th-18th Century Burney Collection Newspapers. 
"secret history" in The Progress of Romance, but she described Manley's New Atalantis as "a work too well known in the last age, thought almost forgotten in the present; a work that partakes of the style of the Romance, and the Novel." In 1810, Anna Laetitia Barbauld would refer to Manley and Haywood as novelists in "On the Origin and Progress of Novel Writing," although she noted that they followed the (licentious) style of Aphra Behn. ${ }^{9}$

By the late eighteenth century, readers of novels did not necessarily recognize the secret history as a category separate from "romance" or "novel." Secret histories, however, had not entirely vanished. In Despotism; Or, The Fall of the Jesuits: A Political Romance, Illustrated by Historical Anecdotes (1811), Isaac D'Israeli referred to the genre as "often a treasure under ground." ${ }^{10}$ By the twentieth century, as Eve Tavor Bannet observes, the secret history still existed but lay on "the wrong side of opposition between truth and scandal, fact and fiction," and was not given serious consideration by literary scholars. ${ }^{11}$ Twentieth-century literary historians, notably Ian Watt, misread secret histories-especially those by the female secret historians and novelists Behn, Manley, and Haywood-as "unrealistic" novels with characters whose names "carried foreign, archaic, or literary connotations which excluded any suggestion of real and contemporary life."12 Of course, in some of Behn's works and almost all of Manley's, these foreignsounding names were chosen precisely because the characters represented real persons recognizable to the public; these names were testimony to libelously recognizable - that is, dangerously realistic-depictions of well-known court and society figures.

8 Clara Reeve, The Progress of Romance through Times, Countries, and Manners (1785; reprint, New York: Garland, 1970), 119.

9 Anna Laetitia Barbauld, "On the Origin and Progress of Novel Writing," in Anna Letitia Barbauld: Selected Poetry and Prose, ed. William McCarthy and Elizabeth Kraft (Peterborough: Broadview Press, 2002), 400-1.

10 [Isaac D'Israeli], Despotism; Or, The Fall of the Jesuits: A Political Romance, Illustrated by Historical Anecdotes (London: Murray, 1811), 2:317, Archive.org.

11 Eve Tavor Bannet 'Secret history': Or, Talebearing Inside and Outside the Secretorie," in Paulina Kewes, The Uses of History in Early Modern England (San Marino: Huntington Library, 2006), 367.

12 Ian Watt, The Rise of the Novel: Studies in Defoe, Richardson and Fielding (Berkeley: University of California Press, 1957), 19. In part, his complaint also stems from overlooking the influence of translated texts from the Continent in his history of the (English) novel, according to Mary Helen McMurran in The Spread of Novels: Translation and Prose Fiction in the Eighteenth Century (Princeton: Princeton University Press, 2010), 28-29. 
Important correctives to studies such as Watt's Rise of the Novel have provided alternative categories for a range of early novelistic texts, including amatory fiction, print entertainment, courtesan's narratives, Oriental tales, or simply prose fiction. ${ }^{13}$ This recent research has not generally focused on the secret history as a separate genre or considered its formal relationship to the developing novel. Nor have these studies addressed why secret histories sometimes appeared to readers as novels, why novelists sometimes marketed their works as secret histories, or why the category eventually slipped into a marginalized corner of novelistic history. Srinivas Aravamudan suggests that "it might be worth revaluating the secret history as a genre of Enlightenment Orientalism, involving parallel systems of reference-both familiar and unfamiliar-allowing for invective and disavowal." ${ }^{14}$ Lennard Davis contends that the novel evolved as a vehicle for offering partisan reflections in a medium not subject to the taxes on pamphlets following the Stamp Act of 1712, and one perhaps less likely to produce an arrest for libel. ${ }^{15}$ I argue that by the mid-eighteenth century many novelists had borrowed narratological tropes of secret history even as secret histories themselves remained a more obviously politicized genre that

13 In Before Novels: The Cultural Contexts of Eighteenth-Century English Fiction (New York: W.W. Norton, 1990), J. Paul Hunter opened up the field in considering a range of pre-novelistic texts, although he does not offer a separate discussion of secret histories as he does for sermons, conduct books, spiritual autobiographies, and travel narratives. Ros Ballaster uses the term "amatory fiction" in Seductive Forms: Women's Amatory Fiction from 16841740 (Oxford: Clarendon Press, 1992); William B. Warner uses the term "print entertainment" in Licensing Entertainment: The Elevation of the Novel Reading in England, 1684-1750 (Berkeley: University of California Press, 1998). Toni Bowers uses the broad category "prose fiction" in a recent discussion of a range of works including both novels and secret histories: see Force or Fraud: British Seduction Stories and the Problem of Resistance, 1660-1760 (Oxford: Oxford University Press, 2011). Alison Conway identifies thematic elements of "courtesan narratives" in both secret histories and novels in The Protestant Whore: Courtesan Narrative and Religious Controversy in England, 1680-1750 (Toronto: University of Toronto Press, 2010). In Enlightenment Orientalism: Resisting the Rise of the Novel (Chicago: University of Chicago Press, 2012), Srinivas Aravamudan points out the historical importance of the Oriental tale and challenges literary scholars to study "the history and theory of prose fiction in its broadest sense rather than just focusing on the overblown story of the rise of the novel" (30).

14 Aravamudan, 207.

15 Davis, 96-101. 
would eventually be less recognizable to scholars as a strand of literary history.

Catherine Gallagher points out that as the eighteenth-century British novel "made fictionality manifest," it simultaneously "discovered" and "obscured fiction." ${ }^{16}$ I contend that the slippery relationship between the secret history and the emerging novel aided the novel in "discovering" itself as fiction, but simultaneously helped obscure the secret history as a separate and eventually forgotten literary category. ${ }^{17} \mathrm{I}$ also propose that one of the reasons for this slippage is that the narrative structure of opposition secret histories-which often made claims to eye-witness truth even as they incorporated narratological ruses to protect the author from libel-helped inaugurate several narratological features associated with the novel by future literary historians: authorial claims to truth and forms of narrative perspective that shift between first- and third-person narration. ${ }^{18}$ The secret historians dismissed by mid-twentieth-century scholars as marginalized writers of romance were in fact central to the eighteenth-century novel's narratological development; in turn, this development eventually left secret histories in the margins of literary history.

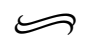

Annabel Patterson identifies two main styles of political secret history: the first is a "tell-all" account of insider secrets without pseudonyms, such as Andrew Marvell's An Account of the Growth of Popery and Arbitrary Government (1677); the second is a keyed account of court intrigue borrowing tropes of romance, such as Delarivier Manley's New Atalantis. ${ }^{19}$ Patterson describes Marvell's Exclusionist secret history as a prototype for a genre that she views as primarily Whig at the end of the seventeenth century. She suggests that Manley's style of keyed secret history was "primarily a feature of Hanoverian party politics" (184). Yet

16 Catherine Gallagher, "The Rise of Fictionality, in History, Geography, and Culture, ed. Franco Moretti, vol. 1, The Novel (Princeton: Princeton University Press, 2006), 337.

17 Aravamudan suggests that Gallagher's analysis of Manley shunts the "genre of the secret history into a historical dead end" (209); in fact, historians of the novel have been doing this since the late eighteenth century.

18 I refer to Watt's appreciation of Jane Austen who, for him, combines a "realism of presentation" with a "realism of assessment" into a "harmonious unity" (297).

19 Patterson, 184-90. 
works such as Hattigé, which appeared in French one year before Marvell's Account, indicate that both styles of secret history were evident in the 1670s and 1680s. Both of these formats appear to have contributed in different ways to the development of narrative perspective associated with later novels.

Marvell's style of tell-all account, in which he offers, ostensibly verbatim, speeches and conversations about the Secret Treaty of Dover, suggests the "air of total authenticity" 20 or the "evidence ... required of narrative to permit it to signify truth to its readers." ${ }^{21}$ The second style of secret history-a work structured as a collection of gossipy anecdotes referring to court and public figures through pseudonyms, for which keys were often published separately-was, I will argue, even more important to novelistic history, although it would be more easily dismissed as "romance" by subsequent literary historians. In these texts, secret historians used layers of narrators and abrupt shifts between third- and first-person narration to diminish their political liability; these narrative structures, I argue, may be seen as precursors to the complex narrative shifts-from "objective narrative" to "coloured narrative" and "free indirect style" - that later novelists would begin developing towards the end of the eighteenth century. ${ }^{22}$

In Hattigé, ou les amours du Roy Tamaran, nouvelle, first published in Cologne in 1676, Brémond establishes a narrative frame that allows him to make bold statements about tyranny and liberty through the voice of a Turkish slave, rather than through his own authorial persona. Translated into English as Hattige, or The Amours of the King of Tamaran, A Novel and printed in Amsterdam under the printer's pseudonym of Simon the African (presumed to be Richard Bentley) in 1680, the work depicts characters whose identities were obvious enough that no published key was necessary in England, although keys were printed for several of the

20 Watt, 32.

21 Michael McKeon, The Origins of the English Novel 1600-1740 (Baltimore: Johns Hopkins University Press, 1986), 17.

22 I am using Graham Hough's terminology here to describe Austen's frequent slight shifts in narrative perspective, not all of which are technically "free indirect discourse," but all of which indicate slippage between firstperson and third-person perspective. Hough, "Narrative and Dialogue in Jane Austen," Critical Quarterly 12, no. 3 (1970): 203-5, doi: http://dx.doi .org/10.1111/j.1467-8705.1970.tb02333.x. 
French editions. ${ }^{23}$ Brémond acknowledges in his autobiography that he turned to writing because he needed money. ${ }^{24} \mathrm{He}$ may have been paid to produce Hattigé by his publisher Richard Bentley, who defended Brémond when the latter was accused of libel by Secretary of State Williamson. ${ }^{25}$ That the work's English edition appeared first in The Hague in 1680 indicates that the publisher offered it as opposition propaganda in support of the Exclusion bills. Hattigé is typical of secret histories mocking Charles II in that it depicts a monarch entirely manipulated by his mistress (the Duchess of Cleveland), who represents both herself and the French King to whom Charles II was bound, financially and politically, after the secret 1670 Treaty of Dover. In this oppositional court narrative, a virtuous Knight of Malta encounters Hattigé (once mistress to the King of Tamaran) as a slave held captive by a brutal and tyrannical captain onboard a seagoing vessel. The Knight finds among the captured women on the vessel Hattigés former attendant in Tamaran's harem, Razié (Razy in the English translation), who recounts for him Hattigés story and describes the monarch's overindulgence of his charming but unfaithful mistress.

In recounting Hattigés story to the Knight of Malta, Razié insists that she is a reliable narrator because she does not omit unflattering details about Hattigés promiscuity. She explains, "You see I have not spar'd her, that I might give you a true Account of her Adventures, which none knew better than I." ${ }^{26}$ Razié also establishes her own moral discernment when she explains that although she has been with Hattigé "ever since she was taken into the Seraglio, [she] never approv'd her Conduct" (108). Despite Razié's conventional view of morality, she does not approve a royalist view of obedience to authority, but encourages

23 René Godenne, preface to Hattigé, ou les amours du Roy de Tamaran (Genève: Slatkine Reprints, 1980), xi.

24 In his preface to a modern facsimile reprint of the 1676 French edition, Godenne cites Brémond's Récit des avantures de M. de Brémond par luy mesme à M. de Lagny, (B.N., MS.N. acq fr. 9185, fol. 19-25): "Largent me manquant" (ix). In this preface, Godenne reaffirms Grobe's identification of Sébastien, not Gabriel, Brémond, as the author of Hattigé (although the reprinted edition oddly includes the wrong name on the modern title page for the reprint).

25 Godenne, xi.

26 [Sébastien Brémond], Hattigé: or the Amours of the King of Tamaran. A Novel (Amsterdam: Simon the African [Richard Bentley], 1680), 107-8. References are to this edition. 
the Knight to liberate Hattigé from the hands of the tyrannical captain: "She would charm you, Sir, did you see her, and 'tis pity a Man as the Captain of the other Vessel should have her in his hands. She would be far better in yours" (108).

Raziés suggestion that the Knight should liberate Hattigé from the captain who captures the vessel (originally heading to Mecca, where she had government permission to travel) articulates an Exclusionist ideology in which subjects recognize that the lawful line of succession might produce tyranny that would justify acts of resistance; this ideology is expressed more strongly by the intradiegetic narration of Razié than by the extradiegetic implied author, who merely emphasizes the courage and disinterestedness of the Knight of Malta-a textual strategy probably useful when Brémond was interrogated for libel. In her narration, Razié simultaneously asserts objectivity, in her claim that she has been so honest as to have not "spar'd her" mistress, and subjective judgment, in her observation to the Knight that "she would be far better in yours," thus making her, rather than the implied author, the judge of proper disinterested moral (and hence political) behaviour towards women. The English translator of the work (identified in the preface as B.B.), coyly describes the work in aesthetic rather than political terms: "The Design is laid with great Art, and managed with as good a Wit" (sig. A4v).

Half a decade after Hattigé appeared in English translation, Tory playwright and translator Behn deployed a simple epistolary structure in Love Letters between a Nobleman and His Sister (1684-87), allowing Silvia to voice royalist ideology and Philander to express the selfish ambition that the Tories ascribed to the Whigs. In the final volume, published in 1687, the letters become longer and more complex; eventually the narrative shifts entirely into third-person narration. ${ }^{27}$ The third volume incorporates fewer letters and more actual scenes of dialogue and description of different characters' thoughts. Caesario offers his mistress Hermione (Lady Henrietta Wentworth) a royal crown, in a passage echoing Hattigé: "If ever Fortune favoured him with

27 It is possible, as Leah Orr has argued, that the third part was not written by Aphra Behn herself. Orr, "Attribution Problems in the Fiction of Aphra Behn," Modern Language Review 108, no. 1 (2013): 30-53, doi: http://dx.doi .org/10.5699/modelangrevi.108.1.0030. In this article, I will continue to refer to the author as Behn. 
a Crown, he would fix it on her Head." ${ }^{28}$ Both Hermione and Silvia's lustful thoughts are recounted. Behn's otherwise extradiegetic narrator also occasionally interjects her own comments. At one point, this implied author addresses the reader- "You may imagine how this News pleas'd Silvia" (2:378). She also offers her eye-witness authority for a description of a church ceremony in Flanders: "I thought my self no longer on Earth" (2:381). These shifts in narrative perspective follow the work's political shift from traditional Royalist ideology into a caustic critique of political loyalty in general. Behn ends the work with deft irony as her narrator describes Philander's (Lord Grey's) political rehabilitation: "Philander ... was at last pardoned, kiss'd the King's Hand, and came to Court in as much Splendour as ever, being very well understood by all good Men" (439). We are not yet at the level of Austen's sustained irony; however, in attempting to satisfy her patron's shifting political loyalties while also rebuking his politically rebellious son, Behn shows a glimmer of the "continual slight shifts in the point of view" that critics have long valued in nineteenth- and twentieth-century novels. ${ }^{29}$

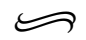

After 1688, with Whig ideology triumphant rather than oppositional, there was less need for subtle shifts in narrative perspective. The anonymous author of the Whiggish The Secret History of the Last Four Monarchs of Great Britain (1691) returns to the open-the-closet style of Marvell's Account, recounting the difficulties caused for the Stuart monarch by the "imprudent Commissions and voluntary Omissions" of James $\mathrm{I} .{ }^{30}$ The author emphasizes the Stuart monarchs' contacts with Rome, reprinting putative royal letters to the Pope; he stresses the dangers of Charles II's "effeminate" tendencies as well as his disregard for the "Fundamental Laws of Society" which made him, not his subjects,

28 Aphra Behn, Love Letters between a Nobleman and His Sister (1684-87), in The Works of Aphra Behn, ed. Janet Todd (Columbus: Ohio State University Press, 1992), 2:324. References are to this edition.

29 Hough uses this description of narrative perspective in Austen (210). Janet Todd delineates Behn's shifting sources of patronage for this work in The Secret Life of Aphra Behn (London and New York: Pandora, 2000), 392.

30 The Secret History of the Last Four Monarchs of Great Britain (London, 1691), 29, Early English Books Online (EEBO). References are to this edition. 
the "Traytor and Rebel" (56). In the appendix, the author stresses the importance of England's deliverance from James II, whose religion forced him to view his "Subjects" as "so many Rebels" (170). This Whiggish version of history, written in the early $1690 \mathrm{~s}$ in support of the reigning monarchs, offers no disguise, no subtle narrative perspective, but a just-the-facts style of narration.

In accounts from this era, written both for and against the Revolution of 1688-89, there is a type of narratological selfawareness in the intertextual references between various secret histories from the reign of William and Mary. In The Detection of the Court and State of England (1694), Roger Coke acknowledges the power of the writer of history, who "governs Fame, measures Deserts; penetrates Intentions; discloses Secrets ... with an undistinguished Arbitrament over Kings and People." ${ }^{31}$ Bullard identifies this kind of significant self-consciousness about the act of claiming (or challenging claims to) insider knowledge as a central stylistic component of the secret history. ${ }^{32}$ By indicating the writer's awareness of the limits of any narrator's claim to truth, such selfconsciousness offers an intellectual backdrop to subsequent narratological developments in the secret history as it was adapted by Tory writers during Queen Anne's reign.

In 1709, Delarivier Manley diverged from the style of Whig secret histories that celebrated the reign of William III. Returning to the opposition style of narrative found in Hattigé, she adapted familiar anecdotes used by Whig writers during Charles II's court to Tory ends during Anne's reign. In her Secret Memoirs and Manners ... From ... the New Atalantis (1709), rather than mocking Charles II, she mocks John Churchill (then a young page at court) for his taking as a lover Charles II's mistress Barbara, then Countess of Castlemaine, subsequently Duchess of Cleveland. Manley moves the structure of the secret history beyond what other opposition writers of her era were accomplishing. Unlike Joseph Browne's The Secret History of Queen Zarah and the Zarazians (1705), Manley's New Atalantis offers much that is new, largely in terms of character development and point of view. ${ }^{33}$

31 Roger Coke, The Detection of the Court and State of England (London, 1694), sig. A4v, EEBO.

32 Bullard, 21-22.

33 J.A. Downie corrects the long-standing erroneous attribution that Queen Zarah was written by Manley, and persuasively attributes the work to Browne. Downie, "What if Delarivier Manley Did Not Write The Secret History of 
In Queen Zarah the eponymous anti-heroine, representing the real-life Duchess of Marlborough, is a caricature of greed and Whiggish ambition. Although Browne lifted several passages almost word-for-word from the English translation of Hattigé in Zarah, ${ }^{34}$ Browne's Zarah is much less sympathetic, in part because there is no secondary narrator comparable to Brémond's Razié to tell her tale sympathetically.

The structure of Manley's The New Atalantis involves several disguising frames to shield the author and printer from prosecution (although they would nonetheless both be arrested for libel in 1709). There is no author given on the title page, which includes the names only of the trade publishers, John Morphew and J. Woodward, who were employed by John Barber as a cover for this risky venture. ${ }^{35}$ The title page also makes the claim that the New Atalantis was an "Island in the Mediterranean" and that the work was "Written Originally in ITALian." The structure of the body text is a travelogue in which Astraea, goddess of Justice, returns to Earth and meets her mother, Virtue, who is frustrated at being abandoned by most mortals. Together they begin a tour of the New Atalantis (England). When they arrive in Angela (London), they are met by Lady Intelligence, groom of the Stole to Princess Fame, on the very day that Princess Olympia (Queen Anne) is crowned queen, following the death of William III.

Bullard elucidates the complexity of this framing through an analysis of the "reductive judgements" offered by Intelligence and Astraea, who appear as ingénues since they are being introduced to "open secrets, common gossip or just historical fact, not previously undiscovered intelligence." For Bullard, Manley "thus creates an impression of complicity between implied author and implied reader based on their shared skepticism of the heavily ironized narrators." Moreover, "if three female figures who form the narrative frame of The New Atalantis are a kind of archetype of Whig secret history, Manley's satirical secret history both

Queen Zarah?” Library 5, no. 3 (2004): 247-64, doi: http://dx.doi.org/10.1093/ library/5.3.247.

34 See Ruth Herman, "Similarities between Delarivier Manley's Secret History of Queen Zarah and the English translation of Hattigé," Notes \& Queries, n.s. 47, no. 2 (2000): 193-96, doi: http://dx.doi.org/10.1093/nq/47.2.193.

35 Carnell, A Political Biography of Delarivier Manley (London: Pickering \& Chatto, 2008), 162. 
appropriates and attacks earlier texts in this tradition." ${ }^{36}$ I would add that Manley not only mocks earlier Whig secret histories through this narrative structure, but also effects further layers of irony through narratological innovations, including passages in which a narrator's voice blends with that of a satirized character.

In describing Henriquez (William of Orange), Intelligence declares that "No Age has ever shown us a Hero made up of greater Compositions!" 37 Touching on his love for his favourite, Bentinck, whom he makes Duke of Portland as soon as he is crowned, Intelligence offers a satirical perspective first from an external comment: "His Ambition was not satisfied! He aim'd at something more!" (2:36). She then adds Bentinck's own perspective in a passage of free indirect discourse, capturing both his satisfaction and his unsatisfied ambition after he has been made Duke: "'Twas Glorious to be a Sovereign Prince, tho' but of a Petty State!" (2:36). Manley's Intelligence does more than offer a reductive judgment from Intelligence’s position as ingénue. By blending Bentinck's thoughts and discourse into Intelligence's narration, Manley allows the Tory reader, sceptical of the ambition of Whig courtiers in Anne's reign, first to feel and then to mock such a breathless expression of Whiggish ambition. Moreover, Portland, as William's favourite, would also represent the Duke of Marlborough (husband to Anne's quondam favourite Sarah, Duchess of Marlborough); Marlborough, by this time, was being mocked for his desire to be made captain general for life-a request that seemed tantamount to asking for a monarchical power beyond what he already wielded as a prince of Mindelheim. ${ }^{38}$ The irony increases as these two favourites, jointly and separately, continue to be mocked for their ambition by different internal narrators, within a narrative whose author signals her Tory values by claiming in her preface to the second volume that her work is Varronian satire, understood in its day as a "natural Tory vehicle." 39

36 Bullard, 93.

37 Delarivier Manley, The New Atalantis (1709), in The Selected Works of Delarivier Manley, ed. Rachel Carnell and Ruth Herman (London: Pickering \& Chatto, 2005), 2:35. References are to this edition.

38 Carnell and Herman, Selected Works of Manley, 2:315n88.

39 Aaron Santesso, "The New Atalantis and Varronian Satire," Philological Quarterly 79, no. 2 (2000): 195, http://tinyurl.com/muuro3z. 
In contrast to Manley's deployment of different narrators' perspectives, Whig secret histories of the same era, parading the dangers of Queen Anne's high church Tory ministers, often took an ostensibly objective view of the action, with occasional digressions into partisan political diatribe. After offering an overview of a century of English history, The Impartial Secret History of Arlus, Fortunatus, and Odolphus, Ministers of State to the Empress of GRAND-INSULA (1710) ends with a warning about the dangers of high church Tories to the monarchy: "God preserve the Empress, Grand Insula, and the Family of Mumlandia, from those Antichristian Designs." ${ }^{40}$ William Graves describes this work as "relatively structured and realistic fiction." ${ }^{41}$ While this narrative is somewhat less fragmented than Manley's anecdotal New Atalantis, its narrative perspective is one-dimensional and its depiction of character is limited to caricatures, in contrast to the more nuanced portraits Manley draws of the courtiers she mocks. ${ }^{42}$ Not surprisingly, this work would not be included in any subsequent anthology of "novels."

Daniel Defoe's The Atalantis Major (1711) would likewise not be viewed by subsequent generations as a novel. Although the work depicts well-known Scottish peers through pseudonyms in the style of Manley, the work deploys a limited narrative perspective and focuses on a limited critique of a particular political moment. As the narrator explains, "My present Relation refers more especially to the Affair of the Election of those representing Nobles, which, as before, the Northern Part of the Island, by a late Treaty of Coalition, were obliged to send up as often as the Soveraign of the Country thought fit to Summon." ${ }^{43}$ Although there is much intentional irony in this project, it does not derive from blended narrative perspective in the text itself, but is more evident in Defoe's correspondence about this work in which he disguises his own authorship to the government authorities who employ him. The most sophisticated developments in narrative perspective can be seen in Defoe's letter to Robert Harley, in which he informs

40 The Secret History of Arlus, Fortunatus, and Odolphus, ed. William Graves (1710; facsimile reprint, New York: Garland, 1972), 40.

41 William Graves, introduction to The Secret History of Arlus, Fortunatus, and Odolphus, ed. Graves, 8.

42 Carnell, A Political Biography of Delarivier Manley, 140.

43 [Daniel Defoe], Atalantis Major, ed. Charles L. Batten (1711; facsimile reprint, Los Angeles: William Andrews Clark Memorial Library, 1979), 9. 
him of the publication of such a work but deflects a confession of his authorship: "It is Certainly Written by Some English man, and I have Some Guess at the Man, but dare not be positive." ${ }^{44}$ In this letter is some of the same coy double-edge voicing evident in the interplay between the sometimes earnest and sometimes ironic retrospective narration in Robinson Crusoe and Moll Flanders, the latter of which is defined in its preface as a "private History" in contrast to the "Romances" and "Novels" with which "the World is so taken up of late." 45

While Manley's secret histories demonstrate innovative narratological structures, the only works in Manley's own lifetime actually sold as "novels" were the novellas published as The Power of Love in Seven Novels, most of which are adaptations of translated nouvelles or novelle from fifteenth- or sixteenthcentury Continental sources. None of these has the originality of plot or narrative perspective that mark Manley's other letters and secret histories, and it seems likely that she prepared this work, which first appeared in December 1719, with an eye towards repeating the commercial success of Haywood's Love in Excess, the first two parts of which had appeared in January and June $1719 .{ }^{46}$ Manley's adaptations of these often violent didactic tales appear as throwbacks to very different Continental cultures and, given how few editions were issued (a single edition in London and another in Dublin), seem to have had little of the appeal to contemporary London society that Manley's earlier political secret histories held for her readers. While Love in Excess saw numerous editions, as did Defoe's Robinson Crusoe, The Power of Love was not reissued, whereas in 1735, eleven years after her death, Manley's New Atalantis and Memoirs of Europe were the first works serialized in the Weekly Novellist.

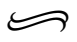

Manley, late in her career, may have tried to match Haywood's early success in the novel genre, but Haywood still viewed

44 Defoe to Harley, 26 December 1710, in The Letters of Daniel Defoe, ed. George Harris Healey (Oxford: Clarendon Press, 1955), 307, quoted in John J. Perry, introduction to Atalantis Major, ed. Batten, viii.

45 Defoe, The Fortunes and Misfortunes of the Famous Moll Flanders (London: John Brotherton, [1722]), sig. A1r, Eighteenth Century Collections Online (ECCO).

46 Carnell, A Political Biography of Delarivier Manley, 233-34. 
Manley's political secret histories as models to emulate. Haywood's Memoirs of a Certain Island Adjacent to the Kingdom of Utopia (1725) follows Manley's New Atalantis, which was reissued in 1720, not only in structure, but also in the choice of satirical targets. The Duke of Marlborough appears in Haywood's work as the late Prince del Carnel. Haywood's satire of the Prince of Wales's intrigue with Mrs Howard echoes Manley's descriptions of court seductions. Haywood's Memoirs of a Certain Island, organized around a visitor to the "Island famous for Arts and Sciences," follows the guided-tour structure of Manley's narratives. Astraea, goddess of justice and important to the iconography of Jacobite ideology, also appears at the end of Haywood's volume. However, because Astraea appears only at the end of the Memoir, there is not the sustained ironic interplay between narrators as in Manley's interchanges between Fame, Intelligence, and Virtue. There are also not as many moments when the main narrator allows the feelings and discourse of one of the characters to colour the narrator's own discourse, perhaps because in this text Haywood was not working, as Manley was, to yoke together disparate elements in the Tory party. Instead, she was signalling "the inadequacy of virtue in a political, social, economic, and legal order that is revealed to be systematically corrupt." ${ }^{37}$

Haywood's second secret history, The Secret History of the Present Intrigues of the Court of Caramania (1727), is somewhat less digressive than Memoirs of a Certain Island. Josephine Grieder suggests that "unlike the Memoirs of a Certain Island, which is nothing but a choppy series of anecdotes connected only by their participants' devotion to the Enchanted Well, Caramania has an integrated plot (albeit with no end), a degree of characterization, and a consistent moral point of view." ${ }^{48}$ Kathryn King observes that, starting with the second volume of Memoirs of a Certain Island, Haywood "departs most significantly from the conventions of the 'secret history' tradition as practiced by Manley (and before her Behn) in partly shifting the focus from high life to the broad middling ranges of society." ${ }^{49}$ Bullard

47 Kathryn R. King, A Political Biography of Eliza Haywood (London: Pickering \& Chatto, 2012), 53.

48 Josephine Grieder, introduction to The Secret History of the Present Intrigues of the Court of Caramania by Eliza Haywood (New York: Garland, 1972), 6.

49 King, A Political Biography of Eliza Haywood, 45-46. 
contends that "although Haywood draws upon the politicized discourses of secrecy and revelation in her works of 1724-25, her contribution to the development of secret history lies as much in the literary as the political sphere." ${ }^{50}$ More particularly, I would argue, Haywood's contribution to the literary sphere also depends on continued developments in narrative perspective demanded by her oppositional political stance.

Haywood's engagement with secret history across her career is more complex than these first two secret histories suggest. Haywood's 1725 translation of Pierre le Pesant de Boisguilbert's Marie Stuart, Reyne d'Escosse: nouvelle historique (1674) as Mary Stuart, Queen of Scots: Being the Secret History of Her Life indicates her familiarity with the confessional political tropes of late seventeenth-century secret history, even though she was more narratologically guarded in her keyed secret histories from the $1720 s^{51}$ By 1729 , in her preface to The Fair Hebrew, cited above, she demonstrates her awareness of the advantages to marketing a work of "Invention" or fiction as "secret history," even as she returned to the traditional keyed format of the secret history for her critique of Robert Walpole in The Adventures of Eovaai. The Fair Hebrew, despite its claim to being a secret history, has neither the textual complexity of Eovaai nor its sophisticated shifts in narrative perspective.

The title page of Eovaai announces the work as a pre-Adamitical secret history. Interwoven with footnotes written by ostensible translators expressing a range of political views, the text nevertheless offers a straightforward critique of Walpole, represented as the evil magician Ochihatou. Haywood achieves in Eovaai an interplay between the perspective of the vulnerable heroine and that of the extradiegetic narrator who regularly allows Eovaai to voice her own thoughts and feelings. We first hear Eovaai regretting aloud her loss of the family jewel that secured her reign, in a passage introduced by "she said": "Why am I alone, of my whole race, born to feel and give Calamity, who am the least able to sustain it in myself, or afford Relief to others." ${ }^{32}$ Later in the text, when Eovaai

50 Bullard, 181.

51 Carnell, "Eliza Haywood and the Narratological Tropes," 105-6.

52 Haywood, The Adventures of Eovaai, Princess of Ijaveo. A Pre-Adamitical History, ed. Earla Wilputte (1736; Peterborough: Broadview Press, 1998), 58. References are to this edition. 
finds some sensible points in a republican's political philosophy, the narrator ironically observes her turn from having previously accepted Ochihatou's encouragement to view monarchs in divine terms: "How fluctuating is Human Nature! How variable in its Inclinations! How little able to withstand the force of Persuasion and Example. She who, by the Insinuations of Ochihatou, had imagin'd Princes might exalt themselves to Gods" (118-19). The narrator acknowledges, with deft and shifting irony, her heroine's simultaneous attraction to a variety of oppositional political ideologies in a work that offers, as Kathryn King explains, "a Bolingbrokean marriage of Tory monarchical ideals and Whig skepticism about the supposed majesty of kings." ${ }^{53}$

This satirical secret history about Walpole, like others from the same era, surpasses in narratological complexity many other works of fiction from the 1730s, a decade recently described as "the absolute low point of production of new novels, histories, and romances in eighteenth-century England." ${ }^{4}$ As Lacy Marschalk, Mallory Anne Porch, and Paula R. Backscheider point out in their fascinating study, this decade appears to have marked a step backward in the development of the novel in England. These authors identify four main categories in their comprehensive list of the publications of the 1730s: "rogue and travel fiction," "novelistic fiction," "epistolary" works, and "the fictions of Robert Walpole." The "novelistic fiction" includes such uninspiring productions as The Millers Beautiful Daughter ... sent Servant to a rich Lady (1730), a tale "by turns violent, sentimental, and didactic"; the authors conclude that "it is a brief, oversimplified riff on the episode with Moll Flanders and the older brother with a more dramatic and moral ending." ${ }^{55}$ Unlike Haywood's Eovaai, with its strikingly original layering of narrative perspective, The Millers Beautiful Daughter is narrated by a largely extradiegetic thirdperson narrator who switches to first-person didactic narration in the final paragraph in order to impart the story's predictable moral lesson: "I hope every Youth that reads this, will have the

53 King, A Political Biography of Eliza Haywood, 89.

54 Lacy Marschalk, Mallory Anne Porch, and Paula R. Backscheider, "The Empty Decade? English Fiction in the 1730s," Eighteenth-Century Fiction 26, no. 3 (2014): 376, doi: http://dx.doi.org/10.3138/ecf.26.3.375.

55 Marschalk, Porch, and Backscheider, 387-88. 
same Honour as Charles, and every young Lady the same heroic Virtue of Polly." ${ }^{56}$

Other works of "novelistic fiction" from this era masqueraded as secret history, as in The Forced Virgin; or the Unnatural Mother. A True Secret History (1730), an "extended narrative with an individualized character with some inner life" that Marschalk, Porch, and Backscheider describe as "one of the ugliest, most violent narratives in the decade." ${ }^{57}$ The inner life of its novelistic heroine is drawn by a sympathetic, if still morally judgmental, extradiegetic narrator; however, the work lacks the level of narratological experimentalism seen in more partisan political secret histories of the era. The tale ends tragically, with infanticide followed by the heroine's suicide. The narrator, falling back on conventions of dramatic epilogue, concludes with a heroic couplet in order to render the moral unmistakable: "From hence, ye Fair, learn to detest the Deed; / Which made this Guilty Maid as Guilty Bleed." ${ }^{8}$

Although not every secret history about Walpole was as narratologically inventive as Haywood's Eovaai, the very need to avoid prosecution for libel appeared to spur narrative complexity. Other satires on Walpole, such as George Lyttelton's Letters from a Persian in England, to His Friend at Ispahan (1735), use an epistolary format in which the main letter-writer, a visitor to England, recounts his experiences and observations with the perspective of an "outsider" not familiar with the customs of the natives. This outsider perspective allows for some ironic observations on corruption and tyranny through the voice of an ostensible visitor to the English court. Marschalk, Porch, and Backscheider conclude that the 1730s were a transformative decade for fiction that "slightly shifted the literary place for cultural critique and modelling from the theatre towards fiction" (409). It also seems that many of these political secret histories contributed more to the narratological development of the novel than other "novelistic fictions." Jonathan Swift's Gulliver's Travels $(1726,1735)$, as Melinda Rabb has demonstrated, is an example of a political secret history in conversation with other earlier

56 The Millers Beautiful Daughter; or True Love and Heroic Virtue of Polly Charlton (London: Mrs. Bailey, [1730?]), 13, ECCO.

57 Marschalk, Porch, and Backscheider, 408.

58 The Forced Virgin; or the Unnatural Mother. A True Secret History (London: W. Trott, 1730), 40. 
histories and secret histories, ${ }^{59}$ yet one that twentieth-century readers would often view as a particularly novelistic satire, in part because of the "retrospective voice of the repentant Narrator." ${ }^{60}$

By the time of Queen Anne's death in 1714, a decline had begun in the importance of secret history, eventually corresponding to a "shift of normative weight from the public reference to the private reference," according to Michael McKeon ${ }^{61}$ Even as secret history had begun this decline, periods of intense political opposition appear to have spurred renewed interest in the form, as those antiWalpole narratives of the 1730s suggest. By the 1740s, novels have absorbed some the creative energy and narratological innovations of earlier political secret histories. Although there was still slippage between the two genres, it would seem that readers and writers recognized a distinction between them. Henry Fielding's The Jacobite's Journal, a fictitious secret history written from the point of view of a staunch Jacobite (1747-48), is a less narratalogically sophisticated work than either of his novels that depict the author's attitude towards the ' 45 in more nuanced terms, incorporating both parody of characters like Partridge and a more complex perspective brought about in digressive conversations about the Rising. ${ }^{62}$ As Lennard Davis suggests, novels themselves could reflect on political events and even express strongly partisan positions in a way that avoided the censorship laws affecting pamphlets. Strongly political novels could be subject to the same charges of libel as political secret histories, of course, but by the 1740 s they appear to have been viewed less suspiciously than less novelistic secret histories, especially as the distance between secret history and novel became more defined to readers and writers.

59 Melinda Rabb, Satire and Secrecy in English Literature from 1650 to 1750 (New York: Palgrave Macmillan, 2007), 128-39.

60 McKeon, Origins, 340. McKeon acknowledges that the "discontinuous quality of Gulliver's character" has prompted modern critics to view the work as more satire than novel (341).

61 McKeon, The Secret History of Domesticity: Public, Private, and the Division of Knowledge (Baltimore: Johns Hopkins University Press, 2005), 612.

62 Anthony Kearney has demonstrated how the Man of the Hill episode, rather than "a clumsy interpolation in the main narrative ... frame[s] both Tom's own history and the Forty-five within a larger perspective." Kearney, "Tom Jones and the Forty-five," Ariel 4, no. 2 (1973): 70, http://ariel.synergiesprairies.ca/ ariel/index.php/ariel/issue/view/59. See also Peter J. Carlton, "Tom Jones and the '45 Once Again," Studies in the Novel 20, no. 4 (1988): 361-73, http://www .jstor.org/stable/29532597. 
Haywood's The Fortunate Foundlings (1744) uses the markers of secret history in its subtitle: "Being the Genuine History of Colonel $M-\longrightarrow r s$ and His Sister, Madame du Pl_-sy, the Issue of the Late Ch-_es M-_rs, Son of the late Duke of $R--l-n$ nd." In the preface, Haywood echoes her preface to The Fair Hebrew by once again acknowledging the tendency of novelists to market their fictions as (true) secret histories: "The many Fictions which lately have been imposed upon the World, under the specious titles of Secret Histories, Memoirs, \&c. \&c. have but given too much room to question the Veracity of every Thing that has the least Tendency that way." She claims that her work is based on "Original Letters, Private Memorandums" (sig. A1r). Whereas modern scholars have not yet identified any real persons or political scandals behind the characters in The Fair Hebrew, Haywood's Fortunate Foundlings is clearly making a political statement through a protagonist who transfers his loyalty from Britain to France in 1708. The title page, however, gives a misleading reference to the Duke of Rutland's family, since there are no persons in his family tree corresponding to the blanked names. ${ }^{63}$ Thus, although the novel expresses strong political views, it is not analogical in the way of earlier keyed secret histories.

Rather than announce her political position openly, Haywood has Horatio, the male foundling, demonstrate his heroism by joining the army (against his father's wishes). When taken prisoner in France, Horatio meets the Chevalier St. George, and swiftly pledges his willingness to give his life for the Chevalier's cause: "If a day should come when you, sir, shall attempt the prize, how fortunate would it be for me to have learned to serve you as I am obliged by much more than my duty, by the most natural and inviolable attachment of my heart, which would render it the greatest blessing I could receive from heaven" (130). By maintaining a largely extradiegetic and omniscient third-person narration, Haywood conveys apparent sympathy for the Jacobite cause through the actions and words of her fictitious characters, who pledge loyalty to the real historical figures in the book: Charles XII of Sweden and James Edward Stuart. Earla Wilputte argues that Haywood uses the references to political disagreements between Charles XII and James Edward Stuart in 1708 as "narratological

63 Rachel Carnell, Partisan Politics, Narrative Realism, and the Rise of the British Novel (New York: Palgrave, 2006), 151, 
doubling" to comment in 1744 on the approaching Jacobite rising. ${ }^{64}$ Carol Stewart identifies the foundlings' father as a figure whose plight represents that of James II. ${ }^{65}$ The work thus appears to function neither entirely allegorically nor entirely analogically, but as a political novel. Viewed as a novel rather than as secret history or satire, its political overtones would be lost to twentiethcentury readers viewing the novel's history in humanistic rather than partisan political terms. ${ }^{66}$

The Fortunate Foundlings does not seem to have provoked an arrest for seditious libel (as would Haywood's 1749 A Letter from H- - G- - g ... to a Particular Friend), despite its flattering depiction of James Edward Stuart and its markers of secret history on its title page. Haywood's 1744 novel appears more potentially seditious than A Letter, given that it clearly contrasts the passivity of a father who did not take sides in the conflict of 1688 with the heroism of Horatio, who boldly declares his support for James Edward Stuart. ${ }^{67}$ A Letter from $H--G--g$, written in firstperson epistolary format, has the feel of some of the ostensible eyewitness accounts of late seventeenth-century secret histories rather than the complexity of narrative perspective of Manley's New Atalantis and Haywood's Eovaai. The title page indicates that $\mathrm{H}-\mathrm{G}-\mathrm{G}-\mathrm{g}$ [Henry Goring] was "One of the Gentlemen of the Bed Chamber of the Young Chevalier ... that attended him ... in his late journey through Germany and elsewhere." ${ }^{18}$ This descriptor alone might make authorities want to question the author for her possible knowledge of the whereabouts of Charles Edward Stuart in the autumn of 1749 (the book was published later that year) even though the descriptions of Stuart are

64 Earla Wilputte, “'Room to Fable Upon': The History of Charles XII of Sweden in Eliza Haywood's The Fortunate Foundlings," Eighteenth-Century Novel 2 (2002): 42.

65 Carol Stewart, "Eliza Haywood's The Fortunate Foundlings: A Jacobite Novel," Eighteenth-Century Life 37, no. 1 (2013): 51-71, doi: http://dx.doi .org/10.1215/00982601-1895208. See also Carnell, Partisan Politics, 150-52; and Carnell, "Eliza Haywood and the Narratological Tropes," 114-16.

66 John Richetti describes Haywood's "pragmatic professionalism" in the structure of The Fortunate Foundlings, representing "her adaptive skills to what the market place seemed to want" (introduction to The History of Jemmy and Jenny Jessamy by Eliza Haywood, ed. John Richetti [Lexington: University of Kentucky Press, 2003], xvi), but he mentions nothing about the novel's political references.

67 Carnell, Partisan Politics, 149-50.

68 [Eliza Haywood], A Letter from $\mathrm{H}-\mathrm{G}-\mathrm{G}$... to a Particular Friend (London, 1749), [i], ECCO. 
so hagiographic that the work might be read as parody. ${ }^{69}$ The structure of a secret history with first-person insider information seems to have caught the authorities' attention more than a more apparently novelistic, though still political, work such as The Fortunate Foundlings. Haywood's arrest for A Letter rather than for either The Fortunate Foundlings or The History of Jemmy and Jenny Jessamy, another work with Jacobite overtones, signals a moment when the slippage between secret history and novel was ending. ${ }^{70}$

Political secret histories-tell-all insider accounts of particular political scandals - would still be written, and still are being written to this day. Like Haywood's A Letter from $\mathrm{H}-$ $G--g$, these subsequent secret histories would not necessarily demonstrate further narratological in novation, while novels would continue to develop increasingly complex and subtle uses of narrative perspective. The narratological innovations of secret histories in the early decades of the eighteenth century spurred narratological developments in the novel in the 1740s and 1750s, when works such as Samuel Richardson's Clarissa, Haywood's Jemmy and Jenny Jessamy, Fielding's Tom Jones, and Charlotte Lennox's Harriot Stuart offer nuanced reflections on the partisan conflicts of their day through a range of narrative perspectives that would be recognizable to future readers as novelistic. ${ }^{71}$

As D'Israeli observed in 1811, secret histories had gone "under ground." Novels, both political and apolitical, would continue to be written, benefitting from the techniques of narrative perspective once deployed by secret historians avoiding libel, and readers of novels still sometimes looked for real persons behind the

69 Wilputte, "Parody in Eliza Haywood's A Letter from $\mathrm{H}--\mathrm{G}--$ g, Esq.," Eighteenth-Century Fiction 17, no. 2 (2005): 207-30, http://dx.doi.org/10.1353/ ecf.2005.0021.

70 For a discussion of the politics of Jemmy and Jenny Jessamy, see Carnell, Partisan Politics, 153-61.

71 See Conway, particularly her final chapter (142-81), for the ways in which novels from the 1740s adopted and adapted figures of the Restoration courtesan that were familiar from earlier secret histories. For a discussion of how early eighteenth-century novelists "humanized" the partisan ideologies of the characters whose ideologies they shared, see Carnell, Partisan Politics, 5-16. For the politics of Lennox's Harriot Stuart, a work usually read as autobiographical rather than political, see Carnell, "Jacobite Ideology and the Emergence of British Self-Identity in Charlotte Lennox's Novels," Age of Johnson 22 (2012): 1-25. 
characters into the nineteenth century. ${ }^{72}$ Novels that functioned in particularly analogical ways would come to be viewed as romans à clef, a term not used in English until the nineteenth century (according to the $O E D)^{73}$ despite its frequent anachronistic application to Manley's secret histories. Meanwhile, political secret histories would increasingly be viewed as falling on the wrong side of the boundaries between literature and conspiracy theory. This disparity, evident already in the early nineteenth century, continues to this day. Insider accounts about the Bill Clinton presidential years, for example, have fallen on both sides of that divide: Primary Colors, A Novel of Politics by Anonymous [Joe Klein] was reviewed in respected newspapers and compared to other political novels, such as Robert Penn Warren's All the King's Men. ${ }^{74}$ By contrast, The Secret Life of Bill Clinton: The Unreported Stories was not taken seriously by book reviewers; its author has been dismissed as one of the "Clinton crazies ... of conservative and sometimes conspiratorial bent." 75 The line to definitely separate the two genres that was drawn when fiction slipped away from secret history in the mid-eighteenth century has not yet been entirely effaced.

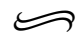

72 Brigid Brophy reads characters in Austen's juvenilia as persons probably recognizable to the Austen family and friends, including a Mr Johnson in "Jack and Alice." Brophy, "Jane Austen and the Stuarts," in Critical Essays on Jane Austen, ed. B.C. Southam (London: Routledge and Kegan Paul, 1968), 22-24. For more on Austen's relationship to secret history and her critique of Whig politics in the age of Queen Anne, see Carnell, "Reading Austen's Lady Susan as Tory Secret History," Lumen 32 (2013): 1-16, doi: http://dx.doi .org/10.7202/1015480ar.

73 Oxford English Dictionary Online (OED Online), s.v. "roman à clef," accessed 9 October 2014, http://www.oed.com/view/Entry/275179.

74 Granting the novel some importance by reviewing it for the New York Times, Michiko Kakutani identifies the author's attempt to follow in the footsteps of All the King's Men, although she concludes "Anonymous, however, is no Robert Penn Warren." Kakutani, "Books of the Times; A Roman a clef to Recent Politics," a review of Primary Colors: A Novels of Politics, by Anonymous, New York Times, 19 January 1996, http://www.nytimes.com/1996/01/19/books/ books-of-the-times-a-roman-a-clef-to-recent-politics.html.

75 The book was not reviewed in the New York Times, but is mentioned in an article about writers who hate Bill Clinton. See Philip Weiss, "Clinton Crazy," New York Times Magazine, 23 February 1997, http://www.nytimes .com/1997/02/23/magazine/clinton-crazy.html. 